\author{
Michal Comporek \\ University of Lodz \\ Department of Business Analysis and Strategy \\ e-mail: michal.comporek@uni.lodz.pl \\ ORCID: 0000-0002-1402-2505
}

\title{
REAL EARNINGS MANAGEMENT IN COMPANIES PUNISHED BY THE UKNF FOR IRREGULARITIES REGARDING IAS/IFRS PRINCIPLES
}

DOI: $10.15611 / \mathrm{pn} .2020 .12 .02$

JEL Classification: G30, M41, M42

(C) 2020 Michał Comporek

This work is licensed under the Creative Commons Attribution-ShareAlike 4.0 International License. To view a copy of this license, visit http://creativecommons.org/licenses/by-sa/4.0/

Quote as: Comporek, M. (2020). Real earnings management in companies punished by the UKNF for irregularities regarding IAS/IFRS principles. Prace Naukowe Uniwersytetu Ekonomicznego we Wroctawiu, 64(12).

\begin{abstract}
The main purpose of the paper is to assess the scope the real earnings management (REM) practices in 20 industrial public companies punished by the Polish Financial Supervision Authority (UKNF) for irregularities regarding compliance with IAS/IFSR. Such a group of violations includes a wide spectrum of irregularities related to: measuring impairment of assets, deviations from accounting standards regarding financial instruments, inadequate fair value measurement, lack of appropriate disclosures, delaying inside information, etc. The empirical research focuses on finding an answer to the question whether the level of REM practices (computed by the Roychowdhury models) in the preceding or following periods differs in a statistically significant manner from the REM activities calculated for the period in which the irregularities were detected. On the other hand, the second approach seeks to examine the relationships between REM and accrual-based earnings management (AEM) practices used to intentionally create financial results in industrial public companies in the tested sample. The conducted research, due to its uniqueness from the perspective of the Polish capital market, seems to be important from the point of view of searching for precise tools to assess the quality of financial statements of public companies.
\end{abstract}

Keywords: real earnings management, fined companies, Polish Financial Supervision Authority, Warsaw Stock Exchange. 


\section{Introduction}

The proper fulfillment of disclosure obligation by companies participating in the organized capital market contributes to the elimination of information asymmetry, which usually leads to privileging the part of investors which, due to their functions, has more knowledge about the financial results achieved by listed companies, plans for their merger or acquisitions, or the current level of demand and supply for given financial instruments. One of the competences of the Polish Financial Supervision Authority (UKNF) is the concern for transparency in the management of companies whose shares are traded on the Warsaw Stock Exchange. This is expressed, among others, by analysing the current and periodic reports of public companies operating on the regulated market, assessing their compliance with the International Financial Reporting Standards (IFRS) guidelines and measuring the quality of data included in the financial statements as well as the non-financial and confidential information of all issuers.

The main purpose of the study is to present the results of the empirical research on real earnings management (REM) practices in industrial public companies listed on the WSE, among which the UKNF found irregularities in the field of the non-fulfillment or unreliable fulfillment of the information obligation under the provisions of: the Act of 29th July 2005 on Public Offering, Conditions Governing the Introduction of Financial Instruments to Organized Trading System and Public Companies and on amendments to other acts (Ustawa z dnia 25 lipca 2005 roku o ofercie publicznej...), the Act of 29th July 2005 on Trading in Financial Instruments (Ustawa z dnia 29 lipca 2005 roku o obrocie instrumentami finansowymi) and/or the Regulation (EU) No 596/2014 of the European Parliament and of the Council of 16 April 2014 on market abuse. Such a group of violations includes a wide spectrum of irregularities related to: measuring impairment of assets, deviations from accounting standards regarding financial instruments, inadequate fair value measurement, lack of appropriate disclosures, and delaying inside information, etc. (see Figure 1). The implementation of these activities had a significant impact on the financial results of the issuer and, in many cases, was characterized by artificial interference in the value of the reported net profit (loss).

The study uses a two-dimensional approach to assessing the scope and directions of REM practices in industrial companies fined by the UKNF. The first focuses on the analysis of the value of four REM indicators distinguished by the Roychowdhury (2006) models, with a simultaneous search for the answer to the question whether the level of REM in the preceding or following periods differs in a statistically significant manner from the REM activities calculated for the period in which the irregularities were detected. In turn, the second approach seeks to examine the relationships between REM and accrual-based earnings management (AEM) practices used to intentionally create financial results in industrial public companies. Assuming that the operations that fall under the concept of REM are clearly different 


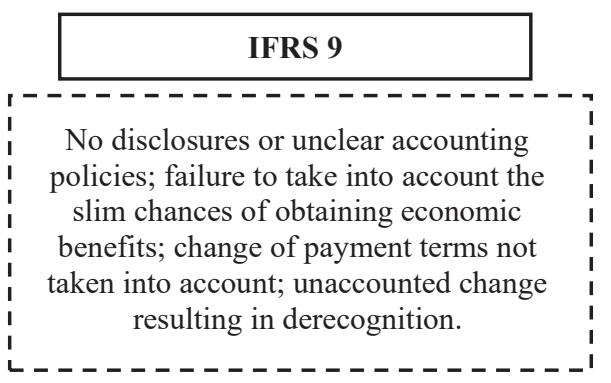

\section{Business continuity, liquidity}

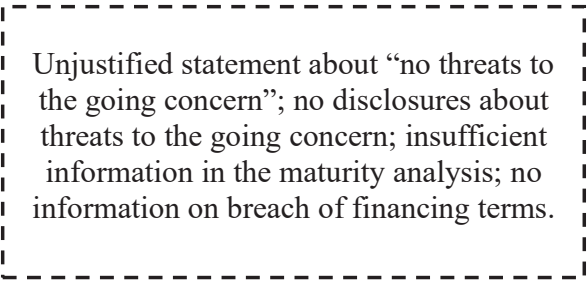

Fair value, taxes

Failure to take into account the condition of the debtor in the valuation of its debt instruments; recognition of the adjusted purchase price as fair value; doubtful recognition of deferred tax assets.

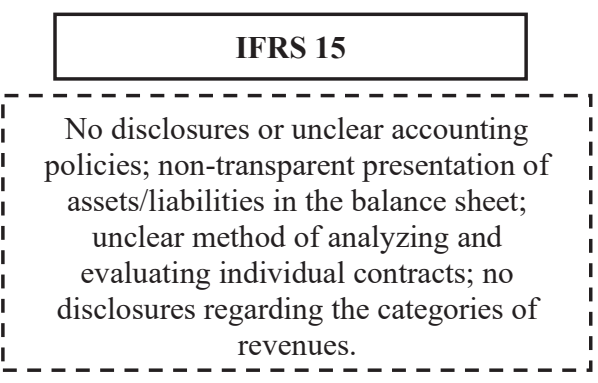

\section{Impairment of assets}

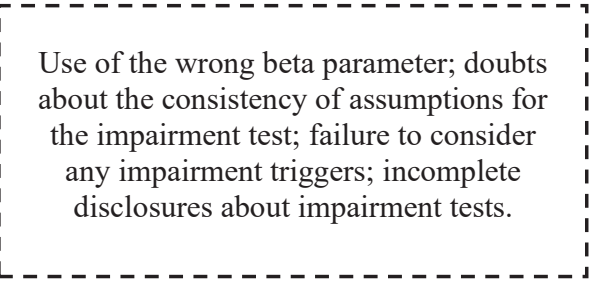

\section{Consolidation, merger}

No disclosures regarding the merger; unclear measurement principles for an investment in an associate; unjustified consolidation of another business entity; no consolidation of the actual subsidiary.

Fig. 1. Selected violations identified during the analysis of financial statements by UKNF

Source: own study.

from the AEM methods (based on solutions that use flexibility in the selection of accounting policies), it seems reasonable to investigate whether managers use the AEM and REM practices complementarily or implement them alternately, treating them as specific substitutes for the intentional shaping of the reported profit (loss) in the enterprise.

The research issues discussed in the paper seem to be innovative from the perspective of the Polish capital market. The problem of earnings management in companies punished by the UKNF has been presented so far in the study by Comporek (2020), although the author's analyses focused solely on accrual-based earnings management in the tested enterprises. In turn, more extensive research on the spectrum of penalties imposed by the UKNF on regulated market participants 
can be found, among others, in the works by: Hendryk, Hońko (2017a), Hendryk, Hońko (2017b), and Kurek, Górowski (2019).

The empirical research was carried out on the basis of data appearing on the website of the Polish Press Agency and disclosed to the public via the Electronic Information Transfer System (ESPI), as well as financial information taken from the Notoria Serwis SA database. A more detailed description of the research methodology is provided in the further part of this paper.

\section{Real earnings management - outline of the issues}

REM activities appear while managers undertake transactions that are inefficient from the firm's perspective, but generate the desired profit or loss in the current period (Ewert \& Wagenhofer, 2005, p. 1104). In other words, REM is a management action that deviates from normal business practices and has suboptimal business consequences. These practices can be oriented to the timing or structuring of the management decision (real business decisions related to the operating, investing or financing activities), overproducing the inventory to lower the cost of goods sold, cutting discretionary expenses (i.e. advertising expenditures, R\&D expenditures, SG\&A expenditures) etc. (Sellami, 2015, p. 207; Huang \& Sun, 2017, pp. 91-104). However, in a wide range of REM techniques, the following activities are also involved, namely:

- selling assets that generate additional revenues for the enterprise or the timing of recognizing revenues from the sale of assets (Bartov, 1993, pp. 840-855);

- buyout and redemption of own shares ("shrink the ship" technique) (Hribar, Jenkins, \& Johnson, 2006, pp. 3-27);

- acquisition and disposal of subsidiaries ("big bet for the future" and "throw out a problem child" techniques);

- use of derivatives and debt instruments (Pincus \& Rajgoral, 2002, pp. 127-160);

- abnormal reduction in product prices in order to increase sales in the current period and apply other measures to accelerate sales (Jackson \& Wilcox, 2000, pp. 3-20).

Business practices related to the concept of REM are aimed at misleading some groups of stakeholders into believing certain financial reporting goals have been met in the normal course of operations (Roychowdhury, 2006, pp. 335-370). Taking into account their distinguishing features, these activities are characterized by: cost-intensive implementation, lower risk of detecting the 'intentionality' of the low motives of undertaken actions; possibility of implementation throughout the entire accounting year, and the limited scope of external control (Comporek, 2019, p. 144; Vladu, 2015, p. 414). Due to the fact that REM practices are not subject to the jurisdiction of any existing control system, they are less frequently the object of external monitoring by the society, media, etc., and negatively affect the company's cash flows, their implementation seems to have clearly negative consequences for the future value of enterprise. 
The indicated distinguishing features of REM can be largely explained by various types of market and contractual 'challenges' faced by the management staff. They have their literary reflection, among others, in the concept of stakeholders value, in the hypothesis of a bonus plan or in the assumptions of agency theory. The observations of Mitchell et al. (1997), referring to the first of the aforementioned theories, lead to the conclusion that managers, in order to obtain satisfactory results from company performance, should pay attention to achieving the goals of various stakeholder groups. At the same time, managers actions are determined by the significance (importance) of a given class of stakeholders, identified on the basis of: power (related to the possibility of influencing the enterprise), legitimacy of the relationship with the company and the urgency of its requirements towards the economic entity. The bonus plan hypothesis means that company managers - in order to maximize their personal remuneration - are more likely to choose such a range of activities that shifts the reported profits from future periods to the current period (Bareja \& Giedroyć, 2016, p. 15). By reporting a high net income, their utility will be maximized through bonuses and incentives. In turn, the framework of the agency theory assumes that the separation of the ownership and control functions in the company results in an information asymmetry between the owner and management. The agent tends to act in his/her own interest, which could affect the occurrence of the phenomenon of negative selection and moral hazard (Hölmstrom, 1979, pp. 74-91). This may give rise to efforts to artificially increase the financial result (in order to achieve the postulated results on which the management incentives are based), or in actions to lower it (when the economic results for a given year clearly exceed a satisfactory level, but future results are uncertain). Another type of agency conflict is related to the concentration of ownership and consists in a contradiction in interests between the majority shareholders who control management decisions, and the minority shareholders (Achleitner, Günther, Kaserer, \& Siciliano, 2014, pp. 431461). This disagreement may lead to attempts to intentionally lower the financial result, aimed at: reducing the dividend payment in the company, increasing the selffinancing of the activity and limiting external financing with equity, which could weaken the control over the company of the existing majority shareholders. BiałekJaworska and Dec $(2019$, p. 12) note at the same time that one of the dimensions of the agency theory potentially affecting earnings management practices is the dissonance between the owners of the enterprise and the lenders. This is based on the fact that creditors providing financial support often impose restrictions on the company with regard to the payment of dividends, buy-back of own shares and obtaining additional foreign capital. In many cases, these restrictions lead to reporting such a level of profits that will fall within the safe ranges requested by creditors.

It should be pointed out that the presented concept, techniques and motives of REM practices are only an outline of a very complex issue of the causes of earnings management in enterprises. 


\section{Data sample and research methodology}

The empirical research was carried out among 20 industrial companies whose shares were traded on the WSE main market for at least eight years in the period 20062017. Additional criteria for qualifying the enterprises for empirical analysis were as follows: availability of annual financial statements, completeness of reported financial data, maintenance of the accounting period ending on December 31, and no liquidation or bankruptcy of the company.

In order to assess the scope of REM practices in the studied sample, a holistic approach proposed by Rochowdhury (2006) was used, which allows to separate three perspectives for REM activities by distinct econometric models and, finally, extract: - abnormal level of cash flow from operations (OCF EM), whose value represents the residual component of the model describing the shaping of operational cash flows using such exogenous variables as: sales revenues and change in sales revenues. This is represented by the equation:

$$
\frac{O C F_{i, t}}{T A_{i, t-1}}=\alpha_{1}\left(\frac{1}{T A_{i, t-1}}\right)+\alpha_{2}\left(\frac{R E V_{i, t}}{T A_{i, t-1}}\right)+\alpha_{3}\left(\frac{\Delta R E V_{i, t}}{T A_{i, t-1}}\right)+\varepsilon_{i, t},
$$

where: $O C F_{i, t}-$ operating cash flows of company $i$ in year $t ; R E V_{i, t}-$ sales revenues of company $i$ in year $t ; T A_{i, t}$ - mean value of total assets of company $i$ in year $t$; $a_{i}, i=0,1, \ldots, k$ are specific regression parameters while $\varepsilon_{i, t}$ denotes error term in regression model.

The negative deviation from zero of OCF_EM indicator illustrates the extent of potential manipulation of the sales volume and relates to managers' decisions to temporarily increase turnover through trade credits and offering exceptionally favourable price discounts.

- abnormal level of production cost (PROD_EM), estimating by using the following regression model:

$$
\frac{P R O D_{i, t}}{T A_{i, t-1}}=\alpha_{0}+\alpha_{1}\left(\frac{1}{T A_{i, t-1}}\right)+\alpha_{2}\left(\frac{R E V_{i, t}}{T A_{i, t-1}}\right)+\alpha_{3}\left(\frac{\Delta R E V_{i, t}}{T A_{i, t-1}}\right)+\alpha_{4}\left(\frac{\Delta R E V_{i, t-1}}{T A_{i, t-1}}\right)+\varepsilon_{i, t},
$$

where: $P R O D_{i, t}-$ production costs (including: cost of goods sold and value of goods and materials sold at purchase prices increased by a change in inventories) of company $i$ in year $t$; other designations - as above.

The positive values of PROD_EM ratio indicate overproduction in the enterprise and reflect the management's efforts to increase the number of manufactured products to a level exceeding the expected market demand, thanks to which it will be possible to divide the fixed costs of production into a larger number of manufactured goods, which will result in lowering the cost unit of products sold. 
- abnormal level of SG\&A expenses (SG\&A_EM), calculated as the difference between the forecasted value and the actual value of discretionary expenses of the enterprise scaled with the average value of total assets from the previous period $^{1}$ :

$$
\frac{S G \& A_{i, t}}{T A_{i, t-1}}=\alpha_{1}\left(\frac{1}{T A_{i, t-1}}\right)+\alpha_{2}\left(\frac{R E V_{i, t-1}}{T A_{i, t-1}}\right)+\varepsilon_{i, t},
$$

where: $S G \& A_{i, t}-$ discretionary selling, general and administrative expenses of company $i$ in year $t$; other designations - as above.

According to Roychowdhury's assumptions, the negative values of the SG\&A_EM coefficient may prove potential REM practices within the company.

Then, the above three Roychowdhury models were used to determine the value of one coherent indicator, illustrating (in a holistic way) the scale of the implemented actions aimed at shaping the financial result by REM. The analytical formula of this measure takes the following form (see: Belal, 2018, pp. 440-456; Cohen \& Zarowin, 2010, pp. 2-19):

$$
T O T_{-} R E M_{i, t}=-O C F_{-} E M_{i, t}+P R O D_{-} E M_{i, t}-S G \& A_{-} E M_{i, t} .
$$

This measure was calculated by multiplying OCF_EM and SG\&A_EM by negative one $(-1)$ so that the larger their value, the higher their upward REM, and then adding together all the resulting amounts plus the value of PROD_EM to derive one single comprehensive measure of REM. Given the way the TOT_REM is defined, the higher the value it yields, the higher the upward REM is expected to be for a firm (Ferentinou \& Anagnostopoulou, 2016, p. 11).

In turn, diagnostic imaging of the degree of $A E M$ practices in the studied sample was tested by means of the Jones model (1991, pp. 193-228) which assumes that the value of operational accruals is determined by two variables: change in sales revenues $(\triangle \mathrm{REV})$ and average value of property, plant and equipment (PPE). Yet the value of discretionary accruals $\left(\mathrm{DACC}_{\text {Jones }}\right.$ ) is based on the difference between the empirical and theoretical value of total accruals (TACC) as the explained variable:

$$
\frac{T A C C_{i, t}}{T A_{i, t-1}}=\alpha_{1}\left(\frac{1}{T A_{i, t-1}}\right)+\alpha_{2}\left(\frac{\Delta R E V_{i, t}}{T A_{i, t-1}}\right)+\alpha_{3}\left(\frac{P P E_{i, t}}{T A_{i, t-1}}\right)+\varepsilon_{i, t},
$$

${ }^{1}$ In the original approach of Roychowdhury, this category includes the abnormal level of discretionary expenses, such as SG\&A expenditures and R\&D expenses. As the last of the above-mentioned pieces is not directly disclosed in the financial statements, in many cases, the analysis of abnormal discretionary expenses narrows down to research on the unexpected level of SG\&A expenses (see: Ferentinou \& Anagnostopoulou, 2016, pp. 2-23; Srivastava, 2019, pp. 1277-1316). 
where: $T A C C_{i, t}$ indicates total accruals of company $i$ in year $t$ (calculated as the difference between net income and operational cash flows); $\triangle R E V_{i, t}$ indicates the change in sales revenues of company $i$ in year $t$; $P P E_{i, t}$ points out an average value of gross property, plant and equipment of company $i$ in year $t$; other designations - as above.

As in the case of REM measures, the accrual-based earnings management scope is demonstrated by the differences between the theoretical and empirical values of the endogenous TACC variable. Then a modified version of the Zang model (2011, pp. 675-703) was used to assess the interdependence between AEM and REM practices. Its analytical formula reads as follows:

$D_{\text {DCC }}$ Jones $\mathrm{i}, t=\alpha_{0}+\alpha_{1} T_{O} O T_{-} R E M_{i, t}+\alpha_{2} L E V_{i, t}+\alpha_{3} S I Z E_{i, t}+\alpha_{4} S G_{i, t}+\alpha_{5} R O A_{i, t}+\varepsilon_{i, t}$,

where: $L E V_{i, t}$ - the debt-to-equity ratio of company $i$ in year $t ; R O A_{i, t}-$ the Return on Assets ratio of company $i$ in year $t ; S I Z E_{i, t}$ - the size of company $i$ in year $t ; S G_{i, t}$ - sales growth of company $i$ in year $t$; other designations - as above.

\section{Empirical results}

The results of the analysis of shaping the average abnormal level of cash flow from operations in the periods for which the UKNF detected irregularities (period $t$ ), as well as in the preceding years $(t-2, t-1)$, or in the years immediately following them $(t+1, t+2)$ indicate that there are no trends in the distribution of the studied variable (Figure 2). For period $t$, for which the sanctions were imposed, the average values of OCF_EM were positive, which from the theoretical point of view proves that there were no REM actions in the analyzed enterprises. In turn, the distribution of the variable describing the abnormal level of production costs is quite different (Figure 3). The obtained results of the analyses show that in the periods for which the UKNF imposed sanctions (period $t$ ), positive mean values of the PROD_EM coefficients were recorded, which may indicate potential actions in the field of REM. On the other hand, in the remaining periods the average values of the abnormal level of production costs were negative $(t-2, t-2, t+2)$ or close to zero $(t+1)$.

Interesting empirical results are provided by the analysis of average values of the coefficients illustrating the abnormal level of SG\&A expenditures in the individual reference periods (Figure 4). The conducted research showed that the lowest, negative values of the SG\&A_EM coefficient were recorded for period $t$, in relation to which irregularities in the compliance with IAS/IFRS principles were detected. This can demonstrate that during this period, REM practices were most widely implemented. Negative average values of the SG\&A_EM measure were also recorded in respect of the periods immediately preceding the year, in relation to which the UKNF detected irregularities $(t-2$ and $t-1)$. Similarly, a holistic analysis of the scope and scale 


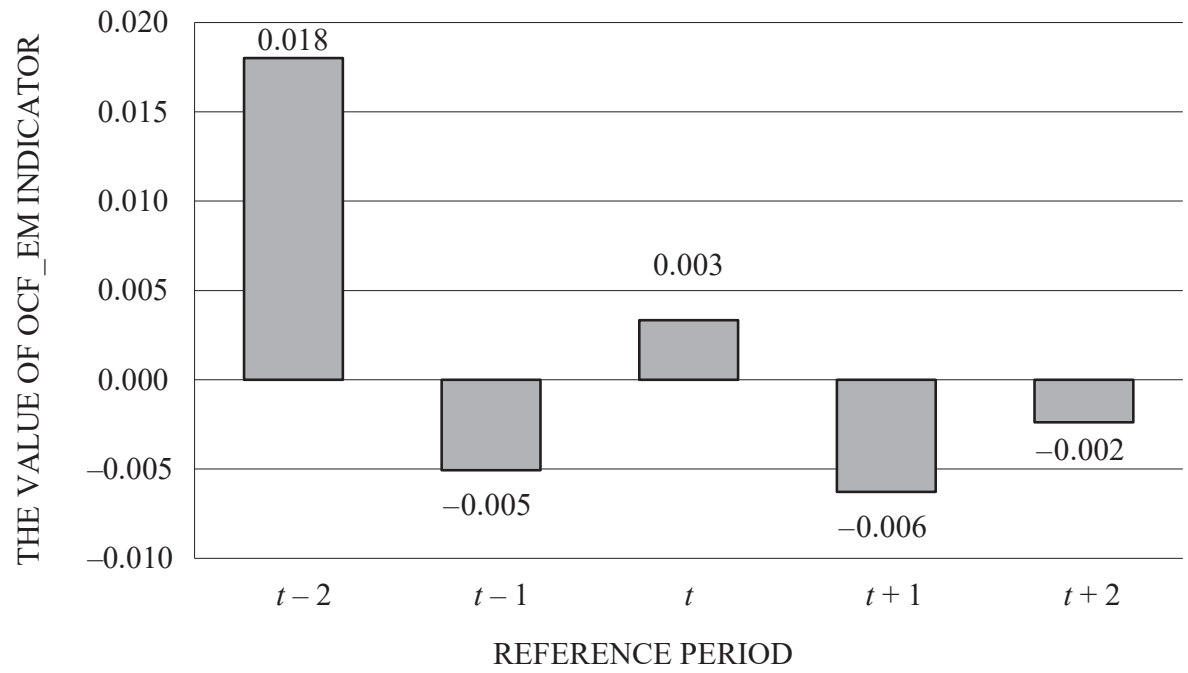

Fig. 2. Average abnormal level of cash flow from operations, calculated for industrial companies fined by the UKNF (by periods)

Source: own study.

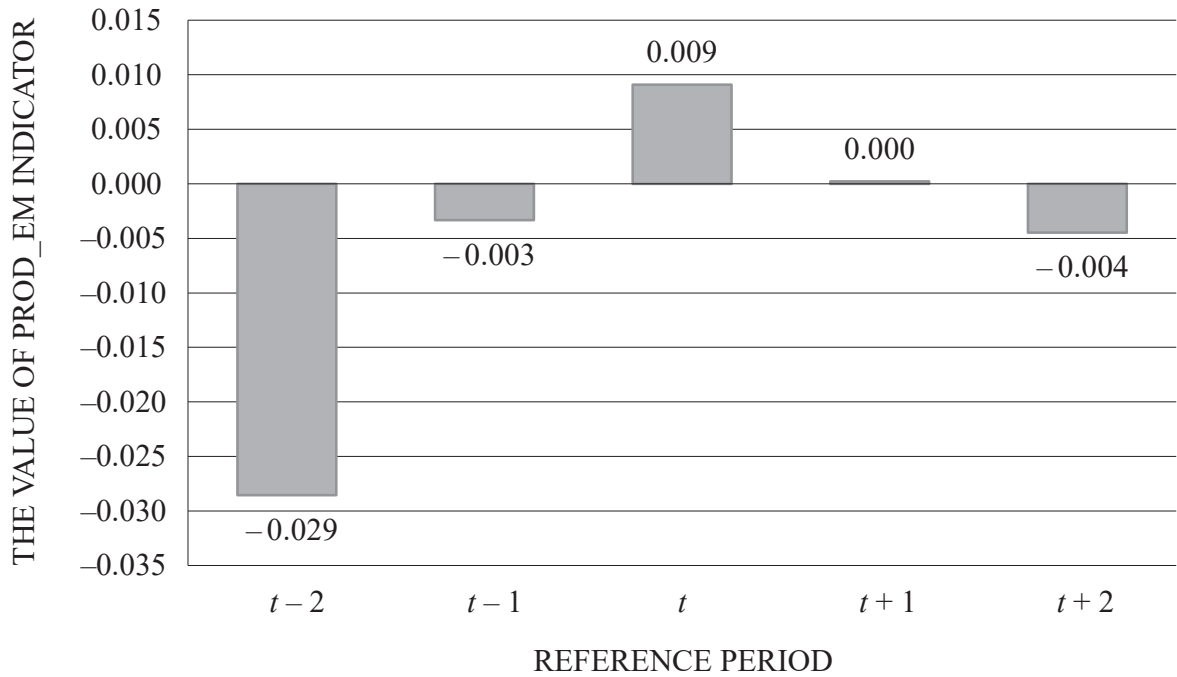

Fig. 3. Average abnormal level of production costs, calculated for industrial companies fined by the UKNF (by periods)

Source: own study. 


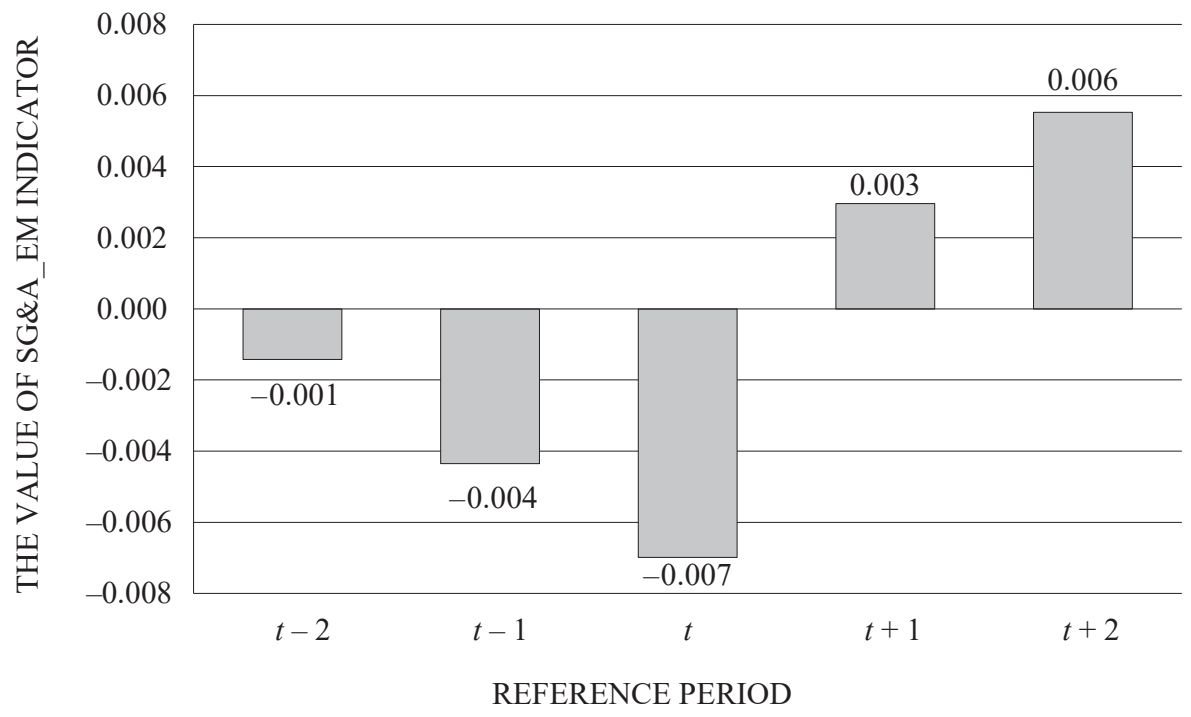

Fig. 4. Average abnormal level of SG\&A expenditures, calculated for industrial companies fined by the UKNF (by periods)

Source: own study.

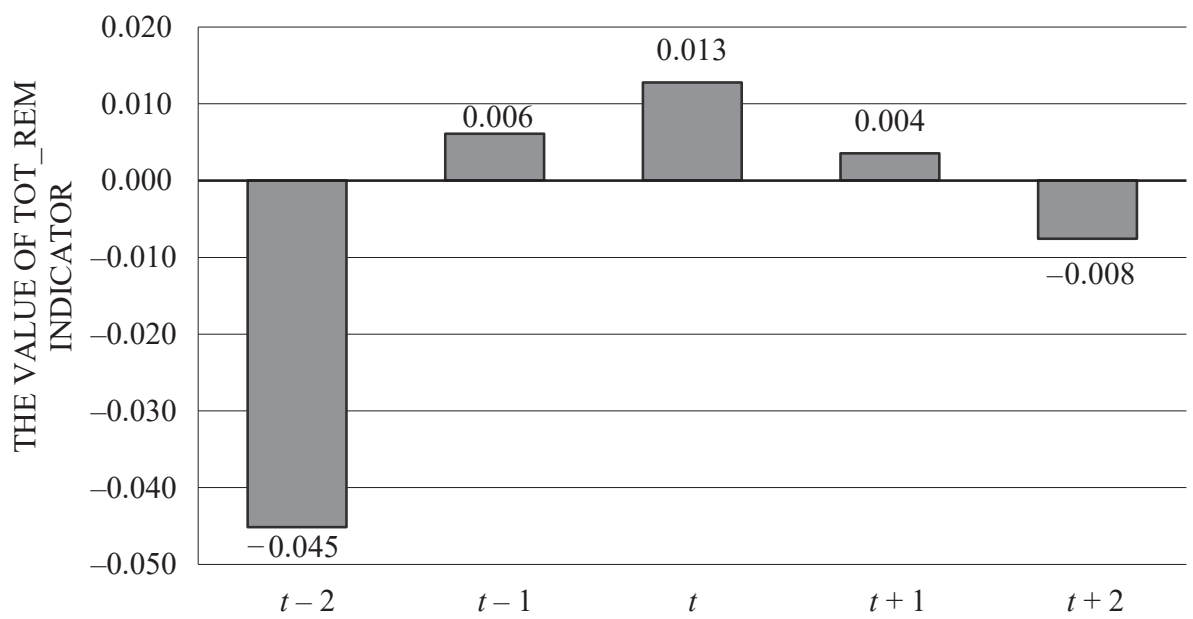

REFERENCE PERIOD

Fig. 5. Average abnormal level of total REM practices, calculated for industrial companies fined by the UKNF (by periods)

Source: own study. 
of REM practices, reflected in the average values of the TOT_REM indicator, showed that in the fined companies in year $t$ REM activities took on the greatest dimension (Figure 5).

For a more complete recognition of the relationship between the values of individual REM coefficients and the sanctions imposed by the UKNF in connection with violating the requirements of IAS/IFRS, the values of measures illustrating the level of earnings management in the preceding $(t-2$ and $t-1)$ and following periods $(t+1$ and $t+2)$, for which irregularities were found, were compared with the results of the REM coefficients calculated for the periods for which the UKNF proved that the accounting framework was violated (period $t$ ). For this purpose, the Wilcoxon signed-rank test was used. The adopted null hypothesis (H0) assumed that there were no differences between the measurements in the studied population, and the alternative hypothesis (H1) stated that the REM indicators values would statistically differ in the adopted reference years. The analysis of empirical research shows that the alternative hypothesis was confirmed only in one case (comparison of PROD_EM values for periods $t-2$ and $t$ ). In the remaining cases, no grounds were found to reject the $\mathrm{H} 0$ hypothesis in favour of the alternative $\mathrm{H} 1$ hypothesis (Table 1). It seems, however, that the obtained results were largely influenced by the low number of the tested sample.

Table 1. Analysis of changes in the median value of REM coefficients in industrial companies punished by the UKNF for non-compliance with the IAS/IFRS principles

\begin{tabular}{|l|l|c|c|c|c|}
\hline \multirow{2}{*}{ REM indicator } & \multicolumn{1}{|c|}{$\begin{array}{c}\text { Wilcoxon } \\
\text { rank-sum test } \\
\end{array}$} & \multicolumn{4}{|c|}{ Compared periods } \\
\cline { 3 - 6 } & of difference in medians & $t-2 / t$ & $t-1 / t$ & $t / t+1$ & $t / t+2$ \\
\hline \multirow{2}{*}{$P R O D_{-} E M$} & $z$-statistics & -2.04 & -0.91 & -0.384 & -0.524 \\
\cline { 2 - 6 } & $p$-value & $\mathbf{0 . 0 4 1 *}$ & 0.363 & 0.701 & 0.600 \\
\hline \multirow{2}{*}{$O C F \_E M$} & $z$-statistics & -0.659 & -0.282 & -0.594 & -0.105 \\
\cline { 2 - 6 } & $p$-value & 0.510 & 0.778 & 0.552 & 0.917 \\
\hline \multirow{2}{*}{$S G \& A_{-} E M$} & $z$-statistics & -1.036 & -0.282 & -1.503 & -1.572 \\
\cline { 2 - 6 } & $p$-value & 0.300 & 0.778 & 0.133 & 0.116 \\
\hline \multirow{2}{*}{$T O T \_R E M$} & $z$-statistics & -1.538 & -0.282 & -0.035 & -0.734 \\
\cline { 2 - 6 } & $p$-value & 0.124 & 0.778 & 0.972 & 0.463 \\
\hline \multirow{2}{*}{$*$ statistically significant relationships at significance level $\alpha=0,05}$. \\
\hline
\end{tabular}

Source: own study.

In-depth research concerned the dependencies between AEM and REM practices in the studied population. The conducted analyses showed, among others, that the obtained structural parameter evaluations confirmed the positive correlation of the endogenous $\mathrm{DACC}_{\text {Jones }}$ variable with the total real earnings management activities (TOT_REM). Beside this, the values of discretionary accruals estimated by the Jones 
model are statistically significantly shaped by such exogenous variables as: leverage (LEV), ROA coefficient and the size of an enterprise (SIZE). Taking the value of the adjusted $\mathrm{R}^{2}$ coefficient $(0.641)$ it can be noted that the tested model is characterized by an average degree of matching with empirical data (Table 2 ).

Table 2. Assessment of structural parameters and statistics for the goodness-of-fit of the tested discretionary accruals model computed by OLS regression

\begin{tabular}{|c|c|c|c|c|c|c|}
\hline \multirow{2}{*}{\multicolumn{2}{|c|}{ Dependent Variable: $\mathrm{DACC}_{\text {Jones }}$}} & \multicolumn{2}{|c|}{$\begin{array}{c}\text { Unstandardized } \\
\text { Coefficients }\end{array}$} & \multirow{2}{*}{$\begin{array}{c}\text { Standardized } \\
\text { Coefficients }\end{array}$} & \multirow[t]{2}{*}{$\mathrm{T}$} & \multirow[t]{2}{*}{ Sig. } \\
\hline & & B & Std. Error & & & \\
\hline \multirow{6}{*}{$\begin{array}{l}\text { Structural } \\
\text { parameters }\end{array}$} & (Constant) & .195 & .061 & - & 3.212 & 0.002 \\
\hline & TOT_REM & .241 & .059 & .202 & 4.102 & 0.000 \\
\hline & LEV & .002 & .001 & .209 & 3.087 & 0.002 \\
\hline & SIZE & -.037 & .011 & -.183 & -3.561 & 0.000 \\
\hline & SG & -.007 & .004 & -.080 & -1.703 & 0.090 \\
\hline & ROA & .675 & .048 & .987 & 14.116 & 0.000 \\
\hline \multirow{2}{*}{ Goodness-of-fit } & $\mathrm{R}$ & R Square & $\begin{array}{l}\text { Adjusted } \\
\text { R Square }\end{array}$ & $\begin{array}{l}\text { Durbin- } \\
\text { Watson }\end{array}$ & $\mathrm{F}$ & Sig. \\
\hline & 0,807 & 0.651 & 0.641 & 2.058 & 62.751 & 0.000 \\
\hline
\end{tabular}

Source: own study.

\section{Conclusion}

The degree, form and time of presenting financial information for specific stakeholders are determined not only by the legal requirements resulting from the existing legislative conditions, but also by the possibilities of the creative shaping of the financial results to achieve specific goals through REM practices.

The obtained results of empirical research presented in the paper showed that in the periods in which the UKNF detected irregularities in the field of non-compliance with the IAS/IFRS guidelines, REM practices were applied to a greater extent than in the periods preceding or following the year when the mentioned irregularities were detected. This remark applies especially to such REM spheres as: excessive increase in production costs and abnormal reduction of SG\&A expenditures. It should be emphasized that the analyses carried out with the Wilcoxon signed-rank test did not prove that the median values of the REM coefficients were statistically significantly different in particular periods, but this result may be caused by the small number of companies tested $(n=20)$. The results of the empirical research realized with OLS-regression also showed that the tested industrial companies implemented strategies of intentional shaping of the financial results through AEM and REM practices in a complementary way. 
The presented research results cannot fulfill the condition of generalization. They contain partial results, opening up prospects for further research on the determinants of REM practices, primarily taking into account a greater number of examined enterprises and their division according to the nature of the committed accounting violations.

\section{References}

Achleitner, A. K., Günther, N., Kaserer, C., \& Siciliano, G. (2014). Real earnings management and accrual-based earnings management in family firms. European Accounting Review, 23, 431-461.

Bareja, K., \& Giedroyć, M. (2016). Motywy wyboru wartości godziwej do wyceny środków trwałych w świetle pozytywnej teorii rachunkowości. Zeszyty Teoretyczne Rachunkowości, 87(143), 9-18.

Bartov, E. (1993). The timing of asset sales and earnings manipulation. The Accounting Review, 68(4), 840-855.

Belal, A. (2018). Real earnings management: A review of literature and future research. Asian Journal of Finance \& Accounting, 10(1), 440-456.

Białek-Jaworska, A., \& Dec, K. (2019). Pożyczki od jednostek powiązanych a wygładzanie zysków przez polskie przedsiębiorstwa prywatne. Zeszyty Teoretyczne Rachunkowości, 102(158), 90-100.

Cohen, D. A., \& Zarowin, P. (2010). Accrual-based and real earnings management activities around seasoned equity offerings. Journal of Accounting and Economics, 50(1), 2-19.

Comporek, M. (2019). Urealniony wymiar oceny zarządzania zyskiem w przemysłowych spółkach giełdowych. Przedsiębiorczość i zarządzanie, tom XX, zeszyt (1), cz. 1, 139-155.

Comporek, M. (2020). Zarządzanie zyskiem w przemysłowych spółkach publicznych ukaranych przez Komisję Nadzoru Finansowego za nieprawidłowości w zakresie przestrzegania wytycznych MSR/ MSSF. Zeszyty Naukowe Uniwersytetu Ekonomicznego w Krakowie, 1(985), 65-84.

Ewert R., \& Wagenhofer, A. (2005). Economics effect of tightening accounting standards to restrict earnings management. The Accounting Review, 80(4), 1101-1124.

Ferentinou, A. C., \& Anagnostopoulou, S. C. (2016). Accrual-based and real earnings management before and after IFRS adoption. Journal of Applied Accounting Research, 17(1), 2-23.

Hendryk, M., \& Hońko, S. (2017a). Przegląd kar nałożonych przez komisję nadzoru finansowego na spółki giełdowe za nieprzestrzeganie wytycznych MSR/MSSF. Studia Ekonomiczne Uniwersytetu Ekonomicznego w Katowicach, 333, 90-104.

Hendryk, M., \& Hońko, S. (2017b). Analiza kar nałożonych przez KNF na spółki notowane na GPW za nieprawidłowości w zakresie pomiaru utraty wartości aktywów. Finanse, Rynki Finansowe, Ubezpieczenia, 4(88), 49-65.

Hölmstrom, B. (1979). Moral hazard and observability. Bell Journal of Economics, 10, 74-91.

Hribar, P., Jenkins, N., \& Johnson, W. (2006). Stock repurchases as an earnings management device. Journal of Accounting and Economics, 41(1-2), 3-27.

Huang, X., \& Sun, L. (2017). Managerial ability and real earnings management. Advances in Accounting, 39, 91-104.

Jackson, S., \& Wilcox, W. (2000). Do managers grant sales price reductions to avoid losses and declines in earnings and sales? Quarterly Journal of Business and Economics, 39(4), 3-20.

Jones, J. (1991). Earnings management during import relief investigations. Journal of Accounting Research, 29(2), 193-228.

Kurek, B., \& Górowski, I. (2019). Kary nakładane przez Komisję Nadzoru Finansowego za naruszenie obowiązków informacyjnych w zakresie sprawozdawczości finansowej. Zeszyty Teoretyczne Rachunkowości, 102(158), 111-129. 
Mitchell, R. K., Agle, B. R., \& Wood, D. J. (1997). Toward a theory of stakeholder identification and salience: Defining the principle of who and what really counts. The Academy of Management Review, 22(4), 853-886.

Pincus, M., \& Rajgoral, S. (2002). The Iinteraction between Aaccrual Mmanagement and Hhedging: Evidence from Ooil and Ggas Ffirms. The Accounting Review, 77(1), 127-160.

Regulation (EU) No 596/2014 of the European Parliament and of the Council of 16 April 2014 on market abuse.

Roychowdhury, S. (2006). Earnings management through real activities manipulation. Journal of Accounting and Economics, 42, 335-370.

Sellami, M. (2015). Incentives and Cconstraints of Rreal Eearnings Mmanagement: The literature review. International Journal of Finance and Accounting, 4(4), 206-213.

Srivastava, A. (2019). Improving the measures of real earnings management. Review of Accounting Studies, 24, 1277-1316.

Ustawa z dnia 25 lipca 2005 roku o ofercie publicznej i warunkach wprowadzania instrumentów finansowych do zorganizowanego systemu obrotu oraz o spółkach publicznych (Dz. U. Nr 184, poz. 1539 z późn. zm.)

Ustawa z dnia 29 lipca 2005 roku o obrocie instrumentami finansowymi (Dz. U. Nr 183, poz. 1538, z późn. zm.)

Vladu, A. (2015). Managerial preferences between accrual-based versus real earnings management. Hyperion International Journal of Econophysics \& New Economy, 8(2), 409-417.

Zang, A. Y. (2011). Evidence on the trade-off between real activities manipulation and accrual-based earnings management. The Accounting Review, 87(2), 675-703.

\section{REALNE ZARZĄDZANIE ZYSKIEM W SPÓŁKACH UKARANYCH PRZEZ KNF ZA NIEPRZESTRZEGANIE WYTYCZNYCH MSR/MSSF}

Streszczenie: Zasadniczym celem artykułu jest ocena praktyk realnego zarządzania wynikiem finansowym w 20 przemysłowych spółkach publicznych ukaranych przez Komisję Nadzoru Finansowego za nieprawidłowości w zakresie przestrzegania wytycznych MSR/IFSR. Do wspomnianej grupy naruszeń należy szerokie spektrum nieprawidłowości związanych m.in. z: wyceną wartości aktywów, odstępstwami od standardów rachunkowości dotyczących instrumentów finansowych, nieodpowiednią wyceną wartości godziwej, brakiem odpowiednich ujawnień, opóźnianiem informacji poufnych itp. Badania empiryczne koncentrują się na statystycznej ocenie wartości wskaźników REM (wyodrębnianych za pomocą modeli Roychowdhury) oraz na relacjach zachodzących między strategiami rzeczowego i księgowego kształtowania wyniku finansowego w badanych przedsiębiorstwach. Zrealizowane badania, ze względu na swoją unikatowość z perspektywy polskiego rynku kapitałowego, wydają się istotne z perspektywy poszukiwania coraz precyzyjniejszych narzędzi umożliwiających ocenę cech jakościowych sprawozdań finansowych spółek publicznych.

Słowa kluczowe: realne zarządzanie zyskiem, spółki ukarane, Komisja Nadzoru Finansowego, Giełda Papierów Wartościowych w Warszawie. 